\title{
Climate Survey in a Mid-Sized Research University Mechanical Engineering Department: Report
}

\author{
Ms. Autumn Turpin, Stanford University
}

Autumn Turpin is a master's student in mechanical engineering studying at Stanford University. She was born and raised in the Bay Area. She has been working with the Designing Education Lab since January '14.

\section{Kai Jun Chew, Stanford University}

Kai Jun (KJ) Chew is a Research Data Analyst in the Mechanical Engineering department at Stanford University. He is leading the effort in the department ABET Accreditation process, conducting continuous improvement of courses and organizing preparation for the next general review. Previously, he has worked in promoting reflection in courses within Stanford University.

\section{Dr. Helen L. Chen, Stanford University}

Helen L. Chen is a research scientist in the Designing Education Lab in the Department of Mechanical Engineering and the Director of ePortfolio Initiatives in the Office of the Registrar at Stanford University. She is also a member of the research team in the National Center for Engineering Pathways to Innovation (Epicenter). Chen earned her undergraduate degree from UCLA and her Ph.D. in Communication with a minor in Psychology from Stanford University in 1998. Her current research interests include: 1) engineering and entrepreneurship education; 2) the pedagogy of ePortfolios and reflective practice in higher education; and 3) reimagining the traditional academic transcript.

\section{Ms. Beth Rieken, Stanford University}

Beth Rieken is a PhD Candidate at Stanford University in the Mechanical Engineering Department. She is in the Designing Education Lab advised by Prof. Sheri Sheppard. Her work focuses on fostering mindful awareness, empathy and curiosity in engineering students. Beth completed a BS in Aerospace Engineering from the University of Virginia in 2010 and a MS in Mechanical Engineering from Stanford in 2012.

\section{Dr. Sheri Sheppard, Stanford University}

Sheri D. Sheppard, Ph.D., P.E., is professor of Mechanical Engineering at Stanford University. Besides teaching both undergraduate and graduate design and education related classes at Stanford University, she conducts research on engineering education and work-practices, and applied finite element analysis. From 1999-2008 she served as a Senior Scholar at the Carnegie Foundation for the Advancement of Teaching, leading the Foundation's engineering study (as reported in Educating Engineers: Designing for the Future of the Field). In addition, in 2011 Dr. Sheppard was named as co-PI of a national NSF innovation center (Epicenter), and leads an NSF program at Stanford on summer research experiences for high school teachers. Her industry experiences includes engineering positions at Detroit's "Big Three:" Ford Motor Company, General Motors Corporation, and Chrysler Corporation.

At Stanford she has served a chair of the faculty senate, and recently served as Associate Vice Provost for Graduate Education. 


\title{
Climate Survey in a Mid-Sized Research University Mechanical Engineering Department: Report
}

\begin{abstract}
This study was inspired by the restructuring of a mid-sized private research university's mechanical engineering undergraduate major. This restructuring consists of offering major "concentrations" in several different areas which were developed based on student and alumni feedback, and redesigning academic advising for mechanical engineering majors.

This time of change is being utilized as a chance to assess the undergraduate student climate in the department more generally. Climate is operationalized around the following factors: sense of community, perceptions of diversity of both faculty and students, and perceptions of inclusivity.

This study is guided by the following evaluation questions:

1. What can be learned about our students' self-beliefs and perceptions of supports? How do they differ by gender and major?

2. How might self-beliefs and perceptions of supports be related?
\end{abstract}

To answer these questions, data were collected via surveys administered to current students who have declared a major in mechanical, biomechanical, or design engineering. The data gathered included students' study skills and habits, their thoughts on program diversity and inclusivity, experiences with faculty, the sense of community of the program, and demographic information including parents' education levels and careers, high school classes and exposure to engineering, and engineering activities outside of school.

We found that there were significant differences between men and women, and mechanical engineering and design students. For men and women, these differences were present in the areas of certain engineering skills, engineering identity, innovation task self-efficacy, engineering task self-efficacy, engineering identity, major fit, and major perception. For mechanical engineering and design students, these differences were present in innovation and engineering task selfefficacy, sense of engineering community, engineering identity, and major perception.

Lastly, we found strong positive correlations between the three supports considered in this work (support of diversity, engineering community support, and faculty support) and a student's sense of fitting into their major. In addition, a strong sense of engineering community support is correlated with greater engineering task self-efficacy, whereas a stronger sense of faculty support is correlated with greater skill beliefs.

\subsection{Introduction}

A Western U.S. mid-sized private research is in the process of restructuring its mechanical engineering undergraduate major; in other words, its Bachelor's of Science in Mechanical Engineering (BSME). Currently, the mechanical engineering major requires introductory mechanical engineering topics (e.g., statics, mechanics of materials, dynamics) as well as upper- 
division thermoscience and mechanical design courses. Based on student and alumni surveys as well as faculty feedback, the BSME is being redesigned to offer topic concentrations in order to provide students with increased flexibility and choice within their major.

The mechanical engineering department at this university administers undergraduate majors in three areas - the BSME and two additional general engineering majors with an emphasis in biomechanical (BS-Engineering, Biomechanical; referred to as BSBME or BME) and design (BS-Engineering, Design referred to as BS-Design). Together, these three majors share a number of core courses, and therefore the students' experience in their respective majors overlaps to some extent.

This restructuring is an opportunity for reflection on the major and, in particular, a time to assess the overall departmental climate for undergraduate students; we call this the ME-related undergraduate climate. We highlight three aspects of this climate: Self-Beliefs, Major and Support Perceptions, and Habits and Activities. The model of climate in Figure 1 was informed by the larger literature on climate and culture (as described in the next section) and considers that self-beliefs are formed by and inform perceptions of the surrounding community and environment. At the same time there is interplay between those self-beliefs and perceptions, and an individual's behaviors.

This paper looks specifically at students' self-beliefs and perceptions of supports at a departmental level, as guided by the following questions:

1. What can be learned about our students' self-beliefs and perceptions of supports? How do they differ by gender and major?

2. How might self-beliefs and perceptions of supports be related?

The results of this study will be used to inform aspects of the restructuring of the mechanical engineering major, as well as interventions to better utilize current resources and possibly design new programs and support services.

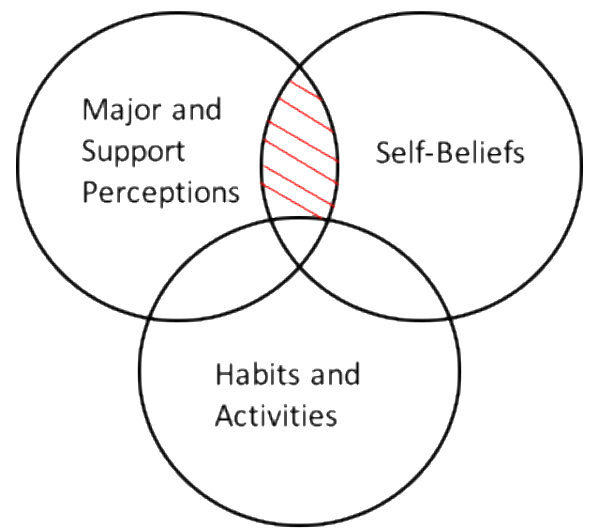

Figure 1: Three Components of Undergraduate Departmental Climate and the Focus of the Current Study (shaded red)

\subsection{Background and Literature Review}




\subsection{Organizational Culture and Organizational Climate}

Organizational culture and organizational climate are two distinct frameworks in organizational psychology. Organizational culture is defined as shared beliefs, values and assumptions that regulate an environment and are taught to newcomers whom joined the said environment. (summarized from p. 362 of Schneider, Ehrhart, \& Macey, 2013). On the other hand, Schneider, Ehrhart, \& Macey (2013) describe organizational climate as "the shared perception of and the meaning attached to the policies, practices, and procedures employees experience and the behaviors they observe getting rewarded and that are supported and expected." (p. 362) The relationship between both concepts is not straightforward since the concept of climate is sometimes viewed as evidence of or a subset of culture, and other times is viewed as an entirely different phenomenon to be studied independently (Schein, 2016). In this paper, however, we consider climate as an artifact of the culture of an environment (Schein, 2016).

\subsection{Study of Culture and Climate in STEM Education}

The study of STEM education culture or climate in higher education has been largely based on the broader frameworks of organizational culture and organizational climate. For example, Godfrey \& Parker (2010) utilized Schein's model to study the culture of an engineering school, resulting in a "conceptual framework of cultural dimensions that has the potential to guide the understanding of culture in the context of engineering education." (p. 5) As another example, Cech \& Waidzunas (2011) loosely adapted the definitions of culture and climate to study lesbian, gay, and bisexual (LGB) students' experiences in an engineering institution. Their ethnographic study on the experiences of LGB students in an engineering school showed how the "chilly climate", a term coined in the work by Hall and Sandler (1982), experienced by LGB students within an engineering institution was a manifestation of the overall heteronormative culture of the engineering field more broadly. These findings are consistent with the notion that climate provides behavioral evidence to reaffirm culture within a setting.

Additional research references the framework of climate primarily through the deployment of climate surveys. Departmental climate was studied to understand the experiences female faculty members working in STEM departments (Callister, 2006; Riffle et al., 2013). Metz, Brainard, \& Gillmore (1999) conducted a pilot climate survey for undergraduate engineering students to study students' self-confidence in engineering courses, academic self-confidence, and perceptions on an engineering degree and other important factors. A similar study by Rinehart \& Watson (1998) in Texas A\&M University focused on gender differences in beliefs, attitudes, and experiences in the engineering school. The survey instrument included questions that involved the barriers women face in pursuing a career in engineering.

The aforementioned works of Metz, et al (1999), Rinehard \& Watson (1998) and Godfrey \& Parker (2010) inspired our current investigation of how climate and cultural frameworks can be used to inform the assessment of departmental climate for a major's restructuring. In summary, for this paper, climate is defined as the shared perceptions of and meaning attached to the policies, practices, and procedures students experience and the behaviors they observe getting rewarded and that are supported and expected in the mechanical engineering department; culture is defined as the shared beliefs, values, and assumptions that regulate, in this case the mechanical 
engineering department, and are taught to new students who declared a major within the department.

\subsection{Engineering Culture and Climate in terms of Gender and Major}

A significant number of studies of in this area focus on the experiences of women in the field, whether as students, faculty, or engineers. Godfrey (2003), in her dissertation, studied the relationship between engineering culture and gender using a case study method, which shows a masculine culture within the engineering field and how the university of interest countered that by encouraging and supporting more women to participate in the field. The climate studies mentioned in the previous section showed that male and female students perceive their respective undergraduate engineering experiences differently (Metz et al., 1999; Rinehart \& Watson, 1998), and highlight the need for additional exploration of gender differences. Differences based on major is another construct of interest in the current study. As noted earlier, the department houses different majors (ME, Design, BME) and each major has its own sub-culture and subclimate. Having different majors within a department creates a "diversity in educational beliefs and attitudes", which could potentially result in tension between majors over "unforeseen differences in beliefs around academic autonomy related to teaching, assessment, and adherence to administrative requirements" (Godfrey \& Parker, 2010, p. 15). In addition, the department's courses also support students in majors outside of mechanical engineering which may also contribute to the experiences of majors as well as the notion of climate in the department. As for the design and deployment of our climate survey, particularly related to instrument questions on students' perceptions on support students get from the engineering community, and faculty support, and on skill-beliefs, and ability confidence, we drew from the Building, Recruiting And Inclusion for Diversity (BRAID) initiative. BRAID is a partnership between the Anita Borg Institute and Harvey Mudd College, and will be discussed further in the Methods section.

\subsection{Methods}

\subsection{Design of the Departmental Climate Assessment Survey Instrument}

The design of a survey instrument to assess departmental climate drew primarily from two existing instruments - the Engineering Majors Survey (EMS) developed by the National Science Foundation (NSF)-funded National Center for Engineering Pathways to Innovation (Epicenter) and a survey developed by BRAID. Additional items were also created to explore issues and questions not addressed by the EMS and BRAID instruments.

The Engineering Majors Survey (EMS) (Gilmartin, et al., 2017) draws upon psychological theories of career choice to ask students about their "innovation self-efficacy", their expectations for the outcomes of innovative behaviors, their innovation interests, and their goals around doing innovative work in their early careers. Designed to measure a comprehensive range of undergraduate learning experiences that may influence students' beliefs about their ability to innovate, the instrument has been administered to over 30,000 engineering juniors and seniors across a nationally representative sample of 27 U.S. engineering schools. Selected items from the EMS for the climate survey included those identifying diverse high school and college learning experiences, as well as the innovation and engineering task self-efficacy scales, and students' interactions in personal and professional contexts. 
The Building, Recruiting, And Inclusion for Diversity (BRAID) initiative aims to increase the percentage of women and underrepresented minority students in computer science. The research efforts employ longitudinal and mixed methods approaches including surveys, interviews and focus groups to address questions regarding the effectiveness of institutions in recruiting and retaining students. Selected items from the BRAID survey for the current climate survey included those identifying student skill beliefs, engineering identity, and faculty support (Sax, Lehman, \& Blaney, 2016; Anita Borg Institute, 2017).

Lastly, a number of items were created to address issues specific to the departmental environment in mechanical engineering and included questions related to how students felt about inclusivity based on gender, race and ethnicity, socioeconomic status, and disability. These new items were evaluated and refined through pilots of the survey instrument with current and recently graduated students from the mechanical engineering department.

Table 1 summarizes the key areas addressed by the survey and the constituent variables; the areas we focus on in this paper are highlighted in gray. The specific times in the variables included in this paper are insulted in the results section.

Table 1. Summary of Climate Survey Areas of Focus and Constituent Variables

\begin{tabular}{|c|c|c|c|}
\hline Self-Beliefs & $\begin{array}{c}\text { Perceptions of } \\
\text { Major }\end{array}$ & $\begin{array}{l}\text { Perceptions of } \\
\text { Support }\end{array}$ & $\begin{array}{c}\text { Habits and } \\
\text { Activities }\end{array}$ \\
\hline Skill Beliefs $^{1}$ & $\begin{array}{c}\text { Major } \\
\text { Perception }^{3}\end{array}$ & Family Support $^{3}$ & $\begin{array}{c}\text { Study and Work } \\
\text { Habits }^{3}\end{array}$ \\
\hline Ability Confidence $^{2}$ & $\begin{array}{l}\text { Engineering } \\
\text { Community }{ }^{1}\end{array}$ & Faculty Support $^{1}$ & $\begin{array}{c}\text { Access to } \\
\text { Resources }^{3}\end{array}$ \\
\hline $\begin{array}{l}\text { Engineering } \\
\text { Identity }^{1}\end{array}$ & & & $\begin{array}{l}\text { Access to Study } \\
\text { Environments } 3\end{array}$ \\
\hline Major Fit ${ }^{3}$ & & & $\begin{array}{c}\text { High School } \\
\text { Activities }^{2}\end{array}$ \\
\hline
\end{tabular}

${ }^{1}$ Items adapted from the BRAID survey instrument

${ }^{2}$ Items adapted from the Engineering Majors Survey

${ }^{3}$ Items created for the Current Departmental Climate Survey

Grey boxes indicate survey items covered in this paper.

\section{Self-Beliefs}

SKILL BELIEFS: These questions were adapted from BRAID to relate directly to engineering, and was used in this situation to measure how confident students felt about their engineering skills. Examples include finding employment, winning an engineering contest, and becoming a leader in engineering. These items specifically emphasized engineering to allow us to see if there were differences in how confident design students felt about their engineering skills compared to mechanical engineering students.

ABILITY CONFIDENCE: These items were adapted from the EMS for use in evaluating student innovation self-efficacy (ISE.6, indicating the original 6 item construct from EMS), 
engineering task self-efficacy (ETSE), and professional/interpersonal self-efficacy. The only change made to this set of items was breaking up one of the engineering task self-efficacy items into three distinct parts. The original prompt read "Conduct experiments, build prototypes, or construct mathematical models to develop or evaluate a design". The altered items distinguished between confidence in conducting experiments, building prototypes, and constructing mathematical models because of a hypothesis that there would be significant differences between how confident mechanical engineering and design students would feel about the individual parts of that question - design students would likely feel more comfortable building prototypes due to the emphasis in the major courses on prototyping, while the mechanical engineering major courses emphasize use of MATLAB and other modeling software more.

ENGINEERING IDENTITY: These items were included from BRAID, adapted to be specifically about engineering, in order to get a sense of to what extent students considered themselves engineers, as well as how they saw themselves fitting in to the engineering community at this college.

MAJOR FIT: This variable addresses student perceptions of belonging in their major. This question asks generally about student perception of belonging and ability to succeed, as well as distinguishing between social vs. academic fit.

\section{Perceptions of Major and Supports}

MAJOR PERCEPTION: In this variable, students were asked about their thoughts on their major's diversity, likelihood of encountering people who looked like them, and how they felt individuals were treated due to race, gender, and disability. The differentiation between belief, encounters, and treatment were made in order to distinguish between perceptions of the department as a whole vs. the actual experiences students are having.

ENGINEERING COMMUNITY: These questions refer to the social support component of belonging to a major both in and beyond the classroom. In addition to asking about friends/social support within the major, students were asked about their connections in the major more broadly.

FACULTY SUPPORT: These questions were combined from a few separate sections on the BRAID survey and adapted to a specific point of feedback at this particular university. Many students do not feel close to their faculty advisor, so students were prompted to think about the faculty member they felt closest to, and to answer these questions with that person in mind. Then, the students were asked whether the person they answered the above items about was their faculty advisor or not.

\section{Other Variables in the Survey}

The survey also asked about students' perception of family support, as well as their study and work habits, access to resources and study environments, and activities in high schools. These variables (except family support) start to describe behaviors, which is the third element of the climate model presented in Figure 1. These other variables will be considered in future analyses. 


\subsection{Survey Piloting and Deployment}

The survey was initially piloted with 10 alumni who graduated as mechanical engineering and design majors, as well as current biomechanical engineering students. Participants were invited to join a pizza dinner where they took the full survey and shared their comments and feedback in a group discussion. Important feedback was given regarding the language used to describe the department and the major, repetitive questions, suggestions to include questions about perceptions of inclusiveness (or lack thereof) towards students with disabilities, and the length of the survey.

\subsection{Description of Sample and Data Analysis}

The survey was administered in fall 2017 to the declared majors (some 300 students) in the mechanical engineering department via an email invitation from the ME department chair, the chair of the Undergraduate Curriculum Committee, the primary graduate student researcher, and the ME Student Services manager. This population included undergraduate mechanical engineering, biomechanical, and design. The study analyses included the mechanical engineering and design majors and excluded the biomechanical engineering majors since the small respondent size of this group would not allow meaningful comparisons by major. Table 2 shows the gender and major breakdown of the survey respondents.

Table 2: Demographics of students who completed the survey

\begin{tabular}{lcc}
\hline Group & Total & $\begin{array}{c}\text { Percent } \\
\text { Women* }\end{array}$ \\
\hline All respondents & 81 & $31.0 \%$ \\
ME Majors & 50 & $22.0 \%$ \\
Design Majors & 21 & $47.0 \%$ \\
BME Majors & 7 & $28.6 \%$ \\
\hline
\end{tabular}

*Students were presented with 8 options for gender (allowing for as much or as little specificity about gender identity as the student desired). All but one respondent recorded male or female; therefore, analysis was conducted along a binary gender division.

The data analysis was completed using $\mathrm{R}$, and any identifying student information was removed before analysis was performed. The primary statistical methods used were descriptive (n, mean, standard deviation), while additional t-tests and some Pearson's $r$ correlations were performed to further examine differences between groups of students and relationships between variables.

\subsection{Results}

\subsection{What we learned about Self-Beliefs Among Our Students}

Here we consider what we learned about students' skill beliefs (Table 3), ability confidence (innovation and engineering task self-efficacies, Tables 4A and 4B), sense of Engineering Identity (Table 5) and their sense of Major Fit (Table 6). These measures give us various windows into how students see themselves as engineers and engineering majors. More specifically, we look at how the items that make up these forms of self-beliefs vary when looking at the majors as a whole (total group), and how they vary across the two largest majors in the department (BSME, BS-Design), and between undergraduate women and men in the department.

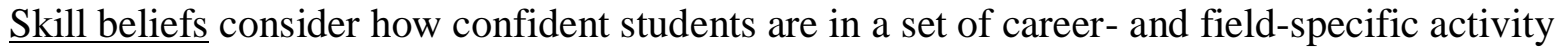
skills (Table 3). The total group is on the "agree" side of things (>3.0/5) for five of the six skills. 
The only one falling towards "disagree" is related to winning an engineering contest (at 2.78). Both women and men, and BSME \& BS-Design majors express similar (and relatively high) agreement with statements related to finding employment and completing their undergraduate degree. We do not see differences in the six skills between BSME and BS-Design majors, though when they are all rolled up into a single "Skill Belief" measure, BS-Design majors are less confident in these particular skill beliefs about career- and field-specific activity skills.

Differences emerge between women and men. Women express lower agreement with the statements about seeing themselves as engineering leaders and their ability to be admitted to graduate school.

Table 3: Comparisons of Skill Beliefs Means by Gender and Major How much do you agree or disagree with the following statements?

\begin{tabular}{|l|c|c|c|c|c|}
\hline & \multicolumn{2}{|c|}{ BSME } & \multicolumn{2}{c|}{ BS-Design } & \\
\hline I believe I can... & $\mathbf{n}$ & $\mathbf{M}($ SD) & $\mathbf{n}$ & $\mathbf{M}(\mathbf{S D})$ & $\boldsymbol{p}$ \\
\hline $\begin{array}{l}\text { Find employment in an area of } \\
\text { engineering interest }\end{array}$ & 44 & $4.09(1.05$ & 20 & $3.60(1.19)$ & NS \\
\hline $\begin{array}{l}\text { Get admitted to a graduate } \\
\text { engineering program }\end{array}$ & 43 & $3.77(1.34)$ & 20 & $3.60(1.00)$ & NS \\
\hline $\begin{array}{l}\text { Complete an undergraduate degree } \\
\text { in engineering }\end{array}$ & 43 & $4.79(0.41)$ & 20 & $4.75(0.44)$ & NS \\
\hline $\begin{array}{l}\text { Win an engineering-related contest } \\
\text { (Solar Decathlon, Formula SAE, } \\
\text { Rube Goldberg Contest, etc.) }\end{array}$ & 42 & $2.98(1.18)$ & 20 & $2.30(1.49)$ & NS \\
\hline $\begin{array}{l}\text { Become a leader in the field of } \\
\text { engineering }\end{array}$ & 44 & $3.80(1.13)$ & 20 & $3.25(1.25)$ & NS \\
\hline $\begin{array}{l}\text { Clearly communicate technical } \\
\text { problems and solutions to a range of } \\
\text { audiences }\end{array}$ & 43 & $4.33(0.78)$ & 19 & $4.00(1.00)$ & NS \\
\hline Overall Skill Beliefs* & -- & $3.96(0.55)$ & -- & $3.58(0.74)$ & \\
\hline
\end{tabular}

\begin{tabular}{|c|c|c|c|c|c|c|c|}
\hline & \multicolumn{2}{|c|}{ Total Group } & \multicolumn{2}{|c|}{ Women } & \multicolumn{2}{|r|}{ Men } & \multirow[b]{2}{*}{$p$} \\
\hline I believe I can... & $\mathbf{N}$ & M(SD) & $\mathbf{n}$ & M(SD) & $\mathbf{n}$ & M(SD) & \\
\hline $\begin{array}{l}\text { Find employment in an area of } \\
\text { engineering interest }\end{array}$ & 71 & $3.97(1.11)$ & 25 & $3.96(0.93)$ & 34 & $4.15(1.02)$ & NS \\
\hline $\begin{array}{l}\text { Get admitted to a graduate } \\
\text { engineering program }\end{array}$ & 70 & $3.71(1.28)$ & 24 & $3.17(1.24)$ & 34 & $4.12(1.23)$ & $* *$ \\
\hline $\begin{array}{l}\text { Complete an undergraduate degree } \\
\text { in engineering }\end{array}$ & 70 & $4.80(0.40)$ & 24 & $4.88(0.34)$ & 34 & $4.82(0.30)$ & NS \\
\hline $\begin{array}{l}\text { Win an engineering-related contest } \\
\text { (Solar Decathlon, Formula SAE, } \\
\text { Rube Goldberg Contest, etc.) }\end{array}$ & 69 & $2.78(1.35)$ & 25 & $2.24(1.27)$ & 32 & $3.19(1.26)$ & $* *$ \\
\hline $\begin{array}{l}\text { Become a leader in the field of } \\
\text { engineering }\end{array}$ & 71 & $3.68(1.19)$ & 25 & $3.36(1.11)$ & 34 & $4.15(1.10)$ & $* *$ \\
\hline $\begin{array}{l}\text { Clearly communicate technical } \\
\text { problems and solutions to a range of } \\
\text { audiences }\end{array}$ & 69 & $4.29(0.84)$ & 24 & $4.12(0.80)$ & 34 & $4.5(0.75)$ & NS \\
\hline Overall Skill Beliefs $\dagger$ & --- & $3.87(-0.62)$ & --- & $3.61(-0.83)$ & ---- & $4.16(0.49)$ & $* * *$ \\
\hline
\end{tabular}


Notes:

Skill-Beliefs Scale Cronbach's Alpha: 0.80

Likert scale, 1-5: Strongly Disagree - Strongly Agree

$\dagger$ Weighted mean computed from the individual variables using respective $\mathrm{n}$ for each variable $* p<.05, * * p<.01, * * * p<.001$

Innovation Self-Efficacy (ISE.6), one of the ability confidence measures on the survey, considers how confident students are in a set of skills/activities related to innovation (Table 4A). When considered as a total group, they are on the "confident" side of things $(>3.0 / 5)$ for all six items, and the total ISE.6 measure is consistent with other published data on engineering college students (Schar, Gilmartin, \& Sheppard 2017). All students are least confident regarding building a large network of contacts with whom they can interact to get ideas for new products or services, at 3.1/5. We see BS-Design majors being significantly more confident than BSME majors regarding asking relevant questions and generating new ideas (which is consistent with differences in program objectives of the two majors).

Differences emerge between women and men, with men being more confident on experimenting to understand, experimenting for new ideas and connecting concepts. Men's ISE.6 is significantly higher than that of women.

\section{Table 4A: Confidence in Innovation Self-Efficacy (ISE.6) Scale by Gender and Major}

How confident are you in your ability to do each of the following at this time?

\begin{tabular}{|c|c|c|c|c|c|c|c|}
\hline & \multicolumn{2}{|c|}{ Total Group } & \multicolumn{2}{|c|}{ Women } & \multicolumn{2}{|r|}{ Men } & \multirow[b]{2}{*}{$p$} \\
\hline & $\mathbf{N}$ & M(SD) & $\mathbf{n}$ & M(SD) & $\mathbf{n}$ & M(SD) & \\
\hline Ask relevant questions & 70 & $4.03(0.93)$ & 25 & $4.12(0.83)$ & 34 & $4.03(1.03)$ & NS \\
\hline $\begin{array}{l}\text { Generate new ideas by observing the } \\
\text { world }\end{array}$ & 70 & $3.94(0.84)$ & 25 & $3.80(0.76)$ & 34 & $4.03(0.83)$ & NS \\
\hline $\begin{array}{l}\text { Experiment as a way to understand } \\
\text { how things work }\end{array}$ & 70 & $3.96(0.73)$ & 25 & $3.60(0.5)$ & 34 & $4.24(0.70)$ & $* * *$ \\
\hline $\begin{array}{l}\text { Actively search for new ideas } \\
\text { through experimenting }\end{array}$ & 70 & $3.87(0.85)$ & 25 & $3.68(0.69)$ & 34 & $4.12(0.88)$ & $*$ \\
\hline $\begin{array}{l}\text { Build a large network of contacts } \\
\text { with whom you can interact to get } \\
\text { ideas for new products or services }\end{array}$ & 69 & $3.10(1.15)$ & 25 & $2.92(1.08)$ & 34 & $3.32(1.22)$ & NS \\
\hline $\begin{array}{l}\text { Connect concepts and ideas that } \\
\text { appear, at first glance, to be } \\
\text { unconnected }\end{array}$ & 70 & $3.90(0.80)$ & 25 & $3.64(0.86)$ & 34 & $4.12(0.73)$ & $*$ \\
\hline Total ISE.6 Confidence $\dagger$ & -- & $3.80(0.31)$ & -- & $3.63(0.36)$ & -- & $3.98(0.30)$ & $* * *$ \\
\hline
\end{tabular}




\begin{tabular}{|c|c|c|c|c|c|}
\hline & \multicolumn{2}{|c|}{ BSME } & \multicolumn{2}{|c|}{ BS-Design } & \multirow[b]{2}{*}{$p$} \\
\hline & $\mathbf{n}$ & M(SD) & $\mathbf{n}$ & M(SD) & \\
\hline Ask relevant questions & 43 & $3.81(1.07)$ & 20 & $4.35(1.03)$ & 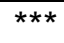 \\
\hline $\begin{array}{l}\text { Generate new ideas by observing the } \\
\text { world }\end{array}$ & 43 & $3.65(0.81)$ & 20 & $4.45(0.83)$ & *** \\
\hline $\begin{array}{l}\text { Experiment as a way to understand } \\
\text { how things work }\end{array}$ & 43 & $3.91(0.72)$ & 20 & $4.10(0.70)$ & NS \\
\hline $\begin{array}{l}\text { Actively search for new ideas } \\
\text { through experimenting }\end{array}$ & 43 & $3.81(0.91)$ & 20 & $4.00(0.88)$ & NS \\
\hline $\begin{array}{l}\text { Build a large network of contacts } \\
\text { with whom you can interact to get } \\
\text { ideas for new products or services }\end{array}$ & 42 & $2.90(1.19)$ & 20 & $3.35(1.22)$ & NS \\
\hline $\begin{array}{l}\text { Connect concepts and ideas that } \\
\text { appear, at first glance, to be } \\
\text { unconnected }\end{array}$ & 43 & $3.86(0.77)$ & 20 & $3.90(0.73)$ & NS \\
\hline Total ISE.6 Confidence $\dagger$ & -- & $3.66(0.35)$ & -- & $4.03(0.36)$ & -- \\
\hline
\end{tabular}

Notes:

Confidence in Innovation Self-Efficacy Scale Cronbach's Alpha: 0.76

Likert scale, 1-5: Strongly Disagree - Strongly Agree

$\dagger$ Weighted mean computed from the individual variables using respective $\mathrm{n}$ for each variable $* p<.05, * * p<.01, * * * p<.001$

Engineering Task Self-Efficacy (ETSE) considers how confident students are in a set of skills/activities related to engineering (Table 4B). BS-Design major students are more confident in designing to requirements and building prototypes than BSME majors. Such high confidence in these two items is consistent with the goals of the BS-Design major.

The total group sampled is on the "confident" side of things for eight of the nine measures. The lowest confidence is expressed in "constructing math models". This is particularly striking for BS-Design majors (as compared with BSME majors) and women (as compared with men). Interestingly, BSME and BS-Design majors have similar overall ETSE scores, whereas women are lower than men. 
Table 4B: Confidence in Engineering Task Self-Efficacy (ETSE) by Gender and Major

\begin{tabular}{|c|c|c|c|c|c|c|c|}
\hline & \multicolumn{2}{|c|}{ Total Group } & \multicolumn{2}{|c|}{ Women } & \multicolumn{2}{|r|}{ Men } & \multirow[b]{2}{*}{$p$} \\
\hline & $\mathbf{N}$ & M(SD) & $\mathrm{n}$ & M(SD) & $\mathrm{n}$ & M(SD) & \\
\hline $\begin{array}{l}\text { Design a new product or project to } \\
\text { meet specified requirements }\end{array}$ & 68 & $3.88(0.94)$ & 25 & $3.76(0.93)$ & 34 & $3.94(0.98)$ & NS \\
\hline $\begin{array}{l}\text { Conduct experiments to develop or } \\
\text { evaluate a design }\end{array}$ & 69 & $3.71(0.96)$ & 25 & $3.44(0.77)$ & 34 & $3.88(1.01)$ & NS \\
\hline $\begin{array}{l}\text { Build prototypes to develop or } \\
\text { evaluate a design }\end{array}$ & 69 & $3.96(0.98)$ & 25 & $3.84(0.90)$ & 34 & $4.00(1.07)$ & NS \\
\hline $\begin{array}{l}\text { Construct mathematical models to } \\
\text { develop or evaluate a design }\end{array}$ & 70 & $2.86(1.15)$ & 25 & $2.60(1.12)$ & 34 & $3.09(1.16)$ & NS \\
\hline $\begin{array}{l}\text { Develop and integrate component } \\
\text { subsystems to build a complete } \\
\text { system or product }\end{array}$ & 70 & $3.21(1.05)$ & 25 & $2.88(0.93)$ & 34 & $3.53(0.99)$ & * \\
\hline $\begin{array}{l}\text { Analyze the operation or functional } \\
\text { performance of a complete system }\end{array}$ & 69 & $3.36(1.06)$ & 25 & $3.04(1.02)$ & 33 & $3.73(1.04)$ & * \\
\hline $\begin{array}{l}\text { Troubleshoot a failure of a technical } \\
\text { component or system }\end{array}$ & 69 & $3.45(0.96)$ & 25 & $3.08(0.81)$ & 33 & $3.76(1.00)$ & ** \\
\hline Overall ETSE Confidencet & -- & $3.49(0.36)$ & -- & $3.23(0.43)$ & -- & $3.70(0.29)$ & $* * *$ \\
\hline
\end{tabular}

\begin{tabular}{|l|c|c|c|c|c|}
\hline & \multicolumn{2}{|c|}{ BSME } & \multicolumn{2}{|c|}{ BS-Design } & \\
\hline & $\mathbf{n}$ & $\mathbf{M}($ SD) & $\mathbf{n}$ & $\mathbf{M}($ SD) & $\boldsymbol{p}$ \\
\hline $\begin{array}{l}\text { Design a new product or project to } \\
\text { meet specified requirements }\end{array}$ & 42 & $3.67(0.93)$ & 19 & $4.37(0.83)$ & $* *$ \\
\hline $\begin{array}{l}\text { Conduct experiments to develop or } \\
\text { evaluate a design }\end{array}$ & 42 & $3.60(0.99)$ & 20 & $3.95(0.83)$ & NS \\
\hline $\begin{array}{l}\text { Build prototypes to develop or } \\
\text { evaluate a design }\end{array}$ & 42 & $3.71(1.04)$ & 20 & $4.45(0.60)$ & $* * *$ \\
\hline $\begin{array}{l}\text { Construct mathematical models to } \\
\text { develop or evaluate a design }\end{array}$ & 43 & $3.02(1.08)$ & 20 & $2.35(1.04)$ & $*$ \\
\hline $\begin{array}{l}\text { Develop and integrate component } \\
\text { subsystems to build a complete } \\
\text { system or product }\end{array}$ & 43 & $3.30(0.96)$ & 20 & $2.95(1.10)$ & NS \\
\hline $\begin{array}{l}\text { Analyze the operation or functional } \\
\text { performance of a complete system }\end{array}$ & 42 & $3.48(0.99)$ & 20 & $3.00(1.08)$ & NS \\
\hline $\begin{array}{l}\text { Troubleshoot a failure of a technical } \\
\text { component or system }\end{array}$ & 42 & $3.48(0.97)$ & 20 & $3.35(0.93)$ & NS \\
\hline Overall ETSE Confidencet & -- & $3.46(0.22)$ & -- & $3.48(0.73)$ & NS \\
\hline
\end{tabular}

Notes:

Confidence in Engineering Task Self-Efficacy Scale Cronbach's Alpha: 0.84

Likert scale, 1-5: Strongly Disagree - Strongly Agree

$\dagger$ Weighted mean computed from the individual variables using respective $\mathrm{n}$ for each variable $* p<.05, * * p<.01, * * * p<.001$

Engineering Identity considers how strongly students identify as an engineer and their engagement with engineering activities (Table 5). Students were universally "high" on caring about performance (4.77/5), interest in applications (4.48/5), and interest in solving problems (4.78/5), as well as seeing themselves as an engineer (4.16/5). We see significant differences between women (vs. men) and BS-Design (vs. BSME) students on feeling welcome in engineering. On the measure of "having things in common with peers" we see that women are 
tilting to "disagree" (at 2.76/5), relative to men (at 3.64/5). Interestingly, the overall student response on this measure was at " $3.19 "$ (perhaps troublingly low).

Table 5: Engineering Identity Scale by Gender and Major

\begin{tabular}{|c|c|c|c|c|c|c|c|}
\hline & \multicolumn{2}{|c|}{ Total Group } & \multicolumn{2}{|c|}{ Women } & \multicolumn{2}{|r|}{ Men } & \\
\hline & $\mathbf{N}$ & M(SD) & $\mathbf{n}$ & $\mathbf{M}(\mathbf{S D})$ & $\mathbf{n}$ & M(SD) & $p$ \\
\hline I see myself as an engineer & 70 & $4.16(1.04)$ & 25 & $4.24(0.78)$ & 34 & $4.26(1.14)$ & NS \\
\hline $\begin{array}{l}\text { I feel like I belong in engineering at } \\
\text { this university }\end{array}$ & 70 & $3.83(1.29)$ & 25 & $3.68(1.28)$ & 34 & $4.09(1.22)$ & NS \\
\hline $\begin{array}{l}\text { I am interested in learning more } \\
\text { about what I can do with } \\
\text { engineering (major, degree, or field) }\end{array}$ & 69 & $4.48(0.82)$ & 24 & $4.20(1.08)$ & 33 & $4.70(0.53)$ & * \\
\hline $\begin{array}{l}\text { Engineering is a big part of who I } \\
\text { am }\end{array}$ & 69 & $3.96(1.18)$ & 25 & $3.76(1.27)$ & 33 & $4.24(0.94)$ & $\mathrm{NS}$ \\
\hline $\begin{array}{l}\text { I feel welcomed in the engineering } \\
\text { community at this university }\end{array}$ & 69 & $3.87(1.16)$ & 25 & $3.56(1.26)$ & 33 & $4.21(0.99)$ & $*$ \\
\hline $\begin{array}{l}\text { Using engineering to solve problems } \\
\text { is interesting }\end{array}$ & 68 & $4.78(0.42)$ & 24 & $4.67(0.48)$ & 33 & $4.88(0.33)$ & NS \\
\hline $\begin{array}{l}\text { I do not have much in common with } \\
\text { the other students in my engineering } \\
\text { classes (reverse coded) }\end{array}$ & 69 & $3.19(1.36)$ & 25 & $2.76(1.30)$ & 33 & $3.64(1.27)$ & * \\
\hline $\begin{array}{l}\text { I care about doing well in } \\
\text { engineering }\end{array}$ & 69 & $4.77(0.46)$ & 25 & $4.72(0.54)$ & 33 & $4.82(0.39)$ & NS \\
\hline Overall Engineering Identity $\dagger^{\dagger}$ & -- & $4.13(0.50)$ & -- & $3.94(0.61)$ & -- & $4.35(0.39)$ & **** \\
\hline
\end{tabular}

\begin{tabular}{|l|c|c|c|c|c|}
\hline & \multicolumn{2}{|c|}{ BSME } & \multicolumn{2}{c|}{ BS-Design } & \\
\hline & $\mathbf{n}$ & M(SD) & $\mathbf{n}$ & M(SD) & $\boldsymbol{p}$ \\
\hline I see myself as an engineer & 43 & $4.26(1.09)$ & 20 & $4.00(0.92)$ & NS \\
\hline $\begin{array}{l}\text { I feel like I belong in engineering at } \\
\text { this university }\end{array}$ & 43 & $4.05(1.15)$ & 20 & $3.5(1.36)$ & NS \\
\hline $\begin{array}{l}\text { I am interested in learning more } \\
\text { about what I can do with } \\
\text { engineering (major, degree, or field) }\end{array}$ & 43 & $4.53(0.63)$ & 20 & $4.45(0.89)$ & NS \\
\hline $\begin{array}{l}\text { Engineering is a big part of who I } \\
\text { am }\end{array}$ & 42 & $4.12(0.97)$ & 20 & $3.65(1.39)$ & NS \\
\hline $\begin{array}{l}\text { I feel welcomed in the engineering } \\
\text { community at this university }\end{array}$ & 42 & $4.12(1.11)$ & 20 & $3.50(1.00)$ & $*$ \\
\hline $\begin{array}{l}\text { Using engineering to solve problems } \\
\text { is interesting }\end{array}$ & 42 & $4.88(0.33)$ & 19 & $4.58(0.51)$ & $*$ \\
\hline $\begin{array}{l}\text { I do not have much in common with } \\
\text { the other students in my engineering } \\
\text { classes (reverse coded) }\end{array}$ & 43 & $3.30(1.44)$ & 19 & $3.00(1.11)$ & NS \\
\hline $\begin{array}{l}\text { I care about doing well in } \\
\text { engineering }\end{array}$ & 42 & $4.86(0.35)$ & 20 & $4.70(0.47)$ & NS \\
\hline Overall Engineering Identity $\dagger$ & -- & $4.26(0.48)$ & -- & $3.92(0.57)$ & $* *$ \\
\hline
\end{tabular}

Notes:

Engineering Identity Scale Cronbach's Alpha: 0.79

Likert scale, 1-5: Strongly Disagree - Strongly Agree

$\dagger$ Weighted mean computed from the individual variables using respective $\mathrm{n}$ for each variable

$* p<.05, * * p<.01, * * * p<.001$ 
Major Fit considers students' feelings of belonging and fitting into their major (Table 6).

Students as a whole are "high" on belonging in their major and that they can succeed in their major. They also indicate good academic fit, and slightly less good social fit. For the overall "Major Belonging" scale, BSME and BS-Design majors are similar. On the other hand, women's overall sense of "fit/belonging" is significantly lower than that of men in the sample.

Table 6: Major Fit Scale by Gender and Major

\begin{tabular}{|c|c|c|c|c|c|c|c|}
\hline & \multicolumn{2}{|c|}{ Total Group } & \multicolumn{2}{|c|}{ Women } & \multicolumn{2}{|r|}{ Men } & \\
\hline & $\mathbf{N}$ & M(SD) & $\mathbf{n}$ & M(SD) & $\mathbf{n}$ & M(SD) & $p$ \\
\hline I feel like I belong in my major & 56 & $4.16(1.06)$ & 25 & $4.00(1.15)$ & 31 & $4.29(0.97)$ & NS \\
\hline $\begin{array}{l}\text { I feel as though I can succeed in my } \\
\text { major }\end{array}$ & 57 & $4.40(0.86)$ & 25 & $4.04(0.10)$ & 32 & $4.69(0.47)$ & $* *$ \\
\hline $\begin{array}{l}\text { I feel like I fit in academically with } \\
\text { my peers in my major }\end{array}$ & 56 & $4.18(1.18)$ & 24 & $4.00(1.29)$ & 32 & $4.31(1.09)$ & NS \\
\hline $\begin{array}{l}\text { I feel like I fit in socially with my } \\
\text { peers in my major }\end{array}$ & 57 & $3.63(1.36)$ & 25 & $3.36(1.32)$ & 32 & $3.84(1.37)$ & NS \\
\hline Overall Major Fit $\dagger$ & -- & $4.09(0.28)$ & -- & $3.85(0.28)$ & -- & $4.28(0.30)$ & ** \\
\hline
\end{tabular}

\begin{tabular}{|l|c|c|c|c|c|}
\hline & \multicolumn{2}{|c|}{ BSME } & \multicolumn{2}{c|}{ BS-Design } & \\
\hline & n & M(SD) & n & M(SD) & $\boldsymbol{p}$ \\
\hline I feel like I belong in my major & 37 & $4.05(1.08)$ & 14 & $4.43(1.09)$ & NS \\
\hline $\begin{array}{l}\text { I feel as though I can succeed in my } \\
\text { major }\end{array}$ & 38 & $4.45(0.69)$ & 14 & $4.57(0.94)$ & NS \\
\hline $\begin{array}{l}\text { I feel like I fit in academically with } \\
\text { my peers in my major }\end{array}$ & 38 & $4.16(1.17)$ & 14 & $4.36(1.15)$ & NS \\
\hline $\begin{array}{l}\text { I feel like I fit in socially with my } \\
\text { peers in my major }\end{array}$ & 38 & $3.61(1.41)$ & 14 & $3.50(1.40)$ & NS \\
\hline Overall Major Fit $\dagger$ & -- & $4.07(0.30)$ & -- & $4.22(0.42)$ & NS \\
\hline
\end{tabular}

Notes:

Major Fit Scale Cronbach's Alpha: 0.79

Likert scale, 1-5: Strongly Disagree - Strongly Agree

$\dagger$ Weighted mean computed from the individual variables using respective $\mathrm{n}$ for each variable $* p<.05, * * p<.01, * * * p<.001$

Based on the data in Tables 3-6 around student self-beliefs, we see several key areas for departmental exploration: how to increase students' confidence in being admitted to engineering graduate school and becoming an engineering leader, how to focus on increasing the confidence of female students in experimenting and troubleshooting, and ways to narrow the gap in "feeling welcomed in engineering" between women and men, and mechanical engineering and design majors. The data highlight some differences we were expecting (design majors are more confident in prototyping and generating ideas, mechanical engineering majors were more confident in constructing math models), and some difference that are more troubling, particularly around women and men's confidence in innovation and engineering task self-efficacy.

\subsection{What we learned about Major and Support Perceptions}

This category investigates students' perceptions of and experiences with being welcomed and included in their major, as well as their levels of support from a variety of sources (peers, family, and faculty). 
Major perception considers students' perceptions on how diversity fits into the department's environment (Table 7). Dimensions of diversity considered are race, gender, socioeconomic status, and disability status. Both women and men are on the side of "disagree" with regards to their major being gender balanced. Interestingly, this perception is much stronger among BSME majors than BS-Design majors. Overall, women perceive their majors as being less diverse than do men.

Table 7: Major Perception Scale by Gender and Major

\begin{tabular}{|c|c|c|c|c|c|c|c|}
\hline & \multicolumn{2}{|c|}{ Total Group } & \multicolumn{2}{|c|}{ Women } & \multicolumn{2}{|r|}{ Men } & \multirow[b]{2}{*}{$p$} \\
\hline & $\mathbf{N}$ & M(SD) & $\mathbf{n}$ & M(SD) & $\mathbf{n}$ & M(SD) & \\
\hline $\begin{array}{l}\text { My major is racially and ethnically } \\
\text { diverse }\end{array}$ & 56 & $3.61(1.29)$ & 24 & $3.08(1.25)$ & 32 & $4.00(1.19)$ & $* *$ \\
\hline My major is gender balanced & 56 & $2.88(1.34)$ & 24 & $2.88(1.3)$ & 32 & $2.88(1.39)$ & $\mathrm{NS}$ \\
\hline $\begin{array}{l}\text { My major is socioeconomically } \\
\text { diverse }\end{array}$ & 51 & $3.00(1.34)$ & 22 & $2.82(1.18)$ & 29 & $3.14(1.46)$ & NS \\
\hline $\begin{array}{l}\text { My major is inclusive of people } \\
\text { with disabilities }\end{array}$ & 48 & $3.25(1.30)$ & 21 & $3.14(1.15)$ & 27 & $3.33(1.41)$ & NS \\
\hline $\begin{array}{l}\text { I feel confident that I will encounter } \\
\text { people of my racial and/or ethnic } \\
\text { background in my classes }\end{array}$ & 56 & $4.21(1.26)$ & 24 & $3.54(1.53)$ & 32 & $4.72(0.68)$ & ** \\
\hline $\begin{array}{l}\text { I feel confident that I will encounter } \\
\text { people of my gender in my classes }\end{array}$ & 57 & $4.49(1.04)$ & 25 & $4.00(1.19)$ & 32 & $4.88(0.71)$ & *** \\
\hline $\begin{array}{l}\text { I feel confident that I will encounter } \\
\text { people with disabilities (visible and } \\
\text { invisible) in my classes }\end{array}$ & 54 & $3.11(1.24)$ & 22 & $2.82(1.18)$ & 32 & $3.31(1.26)$ & NS \\
\hline $\begin{array}{l}\text { I feel as though I am treated } \\
\text { differently because of my race } \\
\text { and/or ethnicity in my classes }\end{array}$ & 56 & $4.32(1.03)$ & 24 & $4.12(1.12)$ & 32 & $4.47(0.95)$ & $\mathrm{NS}$ \\
\hline $\begin{array}{l}\text { I feel as though I am treated } \\
\text { differently because of my gender in } \\
\text { my classes }\end{array}$ & 56 & $3.75(1.42)$ & 25 & $3.08(1.32)$ & 31 & $4.29(1.27)$ & ** \\
\hline $\begin{array}{l}\text { I feel as though I am treated } \\
\text { differently because of my disability } \\
\text { in my classes. }\end{array}$ & 27 & $4.07(1.11)$ & 10 & $3.80(1.14)$ & 17 & $4.24(1.09)$ & NS \\
\hline Overall Major Perception $\dagger$ & -- & $3.66(0.57)$ & -- & $3.31(0.47)$ & -- & $3.93(0.69)$ & $* * *$ \\
\hline
\end{tabular}




\begin{tabular}{|l|c|c|c|c|c|}
\hline & \multicolumn{2}{|c|}{ BSME } & \multicolumn{2}{|c|}{ BS-Design } & M(SD) \\
\hline & n & M(SD) & n & $p$ \\
\hline $\begin{array}{l}\text { My major is racially and ethnically } \\
\text { diverse }\end{array}$ & 38 & $3.79(1.26)$ & 14 & $3.29(1.44)$ & NS \\
\hline My major is gender balanced & 38 & $2.50(1.37)$ & 14 & $3.79(0.89)$ & $* * *$ \\
\hline $\begin{array}{l}\text { My major is socioeconomically } \\
\text { diverse }\end{array}$ & 35 & $3.06(1.41)$ & 12 & $2.67(1.30)$ & NS \\
\hline $\begin{array}{l}\text { My major is inclusive of people } \\
\text { with disabilities }\end{array}$ & 33 & $3.30(1.38)$ & 11 & $3.09(1.30)$ & NS \\
\hline $\begin{array}{l}\text { I feel confident that I will encounter } \\
\text { people of my racial and/or ethnic } \\
\text { background in my classes }\end{array}$ & 38 & $4.45(1.06)$ & 14 & $3.57(1.65)$ & NS \\
\hline $\begin{array}{l}\text { I feel confident that I will encounter } \\
\text { people of my gender in my classes }\end{array}$ & 38 & $4.37(1.20)$ & 14 & $4.93(0.27)$ & $* *$ \\
\hline $\begin{array}{l}\text { I feel confident that I will encounter } \\
\text { people with disabilities (visible and } \\
\text { invisible) in my classes }\end{array}$ & 36 & $3.17(1.25)$ & 13 & $2.92(1.38)$ & NS \\
\hline $\begin{array}{l}\text { I feel as though I am treated } \\
\text { differently because of my race } \\
\text { and/or ethnicity in my classes } \\
\text { (reverse coded) }\end{array}$ & 38 & $4.29(1.11)$ & 13 & $4.38(0.87)$ & NS \\
\hline $\begin{array}{l}\text { I feel as though I am treated } \\
\text { differently because of my gender in } \\
\text { my classes (reverse coded) }\end{array}$ & 37 & $3.70(1.51)$ & 14 & $3.93(1.21)$ & NS \\
\hline $\begin{array}{l}\text { I feel as though I am treated } \\
\text { differently because of my disability } \\
\text { in my classes (reverse coded) }\end{array}$ & 17 & $4.29(1.05)$ & 6 & $4.33(1.03)$ & NS \\
\hline Overall Major Perception $\dagger$ & -- & $3.67(0.64)$ & -- & $3.68(0.68)$ & NS \\
\hline
\end{tabular}

Notes:

Major Perception Scale Cronbach's Alpha: 0.69

Likert scale, 1-5: Strongly Disagree - Strongly Agree

$\dagger$ Weighted mean computed from the individual variables using respective $\mathrm{n}$ for each variable $* p<.05, * * p<.01, * * * p<.001$

Engineering community considers students' connections to peers (Table 8). All students express strong agreement regarding having friends outside of their major (4.58/5). Interestingly, BSDesign majors express significantly greater agreement to knowing more students in other majors within the ME department (meaning BSME and BME majors) than do BSME majors; this is curious as the numbers of BS-Design and BSME majors are comparable, and they take a number of classes together. Worrisome is that all students lean towards "disagree" that their major has a strong out-of-classroom community. 
Table 8: Engineering Community Scale by Gender and Major

\begin{tabular}{|l|c|c|c|c|c|c|c|}
\hline & \multicolumn{2}{|c|}{ Total Group } & \multicolumn{2}{|c|}{ Women } & \multicolumn{2}{|c|}{ Men } & \\
\hline & $\mathbf{N}$ & $\mathbf{M}(\mathbf{S D})$ & $\mathbf{n}$ & $\mathbf{M}(\mathbf{S D})$ & $\mathbf{n}$ & $\mathbf{M}(\mathbf{S D})$ & $\boldsymbol{p}$ \\
\hline $\begin{array}{l}\text { My major has a strong out-of- } \\
\text { classroom community }\end{array}$ & 61 & $2.84(1.49)$ & 25 & $2.60(1.32)$ & 33 & $2.85(1.56)$ & NS \\
\hline $\begin{array}{l}\text { I feel as though I have many friends } \\
\text { in my major }\end{array}$ & 61 & $3.72(1.36)$ & 25 & $3.24(1.39)$ & 33 & $4.03(1.29)$ & $*$ \\
\hline $\begin{array}{l}\text { I have people in my major that I can } \\
\text { go to with questions about school }\end{array}$ & 61 & $3.95(1.24)$ & 25 & $3.88(1.09)$ & 33 & $3.97(1.38)$ & NS \\
\hline $\begin{array}{l}\text { I feel as though I have support and } \\
\text { encouragement to stay in my major } \\
\text { from my peers }\end{array}$ & 60 & $4.58(0.93)$ & 24 & $4.75(0.53)$ & 33 & $4.42(1.15)$ & NS \\
\hline $\begin{array}{l}\text { I have many friends outside of my } \\
\text { major }\end{array}$ & 61 & $3.98(1.27)$ & 25 & $3.84(1.31)$ & 33 & $4.00(1.27)$ & NS \\
\hline $\begin{array}{l}\text { I know many people from the other } \\
\text { majors in my department }\end{array}$ & 62 & $3.19(1.32)$ & 25 & $3.20(1.22)$ & 34 & $3.09(1.40)$ & NS \\
\hline Overall Engineering Community† & -- & $3.71(0.56)$ & -- & $3.58(0.67)$ & -- & $3.72(0.56)$ & NS \\
\hline
\end{tabular}

\begin{tabular}{|l|c|c|c|c|c|}
\hline & \multicolumn{2}{|c|}{ BSME } & \multicolumn{2}{c|}{ BS-Design } & \\
\hline & $\mathbf{n}$ & M(SD) & $\mathbf{n}$ & M(SD) & $\boldsymbol{p}$ \\
\hline $\begin{array}{l}\text { My major has a strong out-of- } \\
\text { classroom community }\end{array}$ & 39 & $2.87(1.61)$ & 17 & $2.94(1.34)$ & NS \\
\hline $\begin{array}{l}\text { I feel as though I have many friends } \\
\text { in my major }\end{array}$ & 39 & $3.82(1.32)$ & 17 & $4.06(1.14)$ & NS \\
\hline $\begin{array}{l}\text { I have people in my major that I can } \\
\text { go to with questions about school }\end{array}$ & 39 & $3.85(1.35)$ & 17 & $4.18(1.01)$ & NS \\
\hline $\begin{array}{l}\text { I feel as though I have support and } \\
\text { encouragement to stay in my major } \\
\text { from my peers }\end{array}$ & 39 & $3.90(1.39)$ & 17 & $4.12(0.99)$ & NS \\
\hline $\begin{array}{l}\text { I have many friends outside of my } \\
\text { major }\end{array}$ & 39 & $4.44(1.10)$ & 17 & $4.88(0.33)$ & $*$ \\
\hline $\begin{array}{l}\text { I know many people from the other } \\
\text { majors in my department }\end{array}$ & 39 & $2.85(1.31)$ & 17 & $3.76(1.03)$ & $* *$ \\
\hline Overall Engineering Community† & -- & $3.62(0.58)$ & -- & $3.99(0.58)$ & $* *$ \\
\hline
\end{tabular}

\section{Notes:}

Engineering Community Scale Cronbach's Alpha: 0.79

"Community" refers to the Department of Mechanical Engineering, which includes 4 majors:

Mechanical Engineering, Design, Biomechanical Engineering, Engineering Physics.

Likert scale, 1-5: Strongly Disagree - Strongly Agree

$\dagger$ Weighted mean computed from the individual variables using respective $\mathrm{n}$ for each variable

$* p<.05, * * p<.01, * * * p<.001$

Faculty Support considers students' connections to faculty (Table 9). In five of the six items, students were in agreement that they are comfortable asking faculty questions (3.61/5), and feel that faculty are respectful (3.95/5). It will be important to consider in restructuring the advising model for the BSME whether or not we as a department are satisfied with scores that are less than four. The one item, perhaps unsurprisingly, that students disagreed with was regarding feeling comfortable discussing personal/life questions with faculty. 
Table 9: Faculty Support Scale by Gender and Major

\begin{tabular}{|c|c|c|c|c|c|c|c|}
\hline & \multicolumn{2}{|c|}{ Total Group } & \multicolumn{2}{|c|}{ Women } & \multicolumn{2}{|r|}{ Men } & \multirow[b]{2}{*}{$p$} \\
\hline & $\mathbf{N}$ & M(SD) & $\mathbf{n}$ & M(SD) & $\mathrm{n}$ & M(SD) & \\
\hline $\begin{array}{l}\text { I feel comfortable asking my faculty } \\
\text { contact questions about what } \\
\text { courses to take }\end{array}$ & 61 & $3.61(1.50)$ & 25 & $3.72(1.40)$ & 34 & $3.53(1.58)$ & NS \\
\hline $\begin{array}{l}\text { I feel like my faculty contact } \\
\text { respects me }\end{array}$ & 62 & $3.95(1.14)$ & 25 & $3.88(1.05)$ & 34 & $4.03(1.19)$ & NS \\
\hline $\begin{array}{l}\text { I feel like my faculty contact wants } \\
\text { me to succeed }\end{array}$ & 62 & $4.11(1.10)$ & 25 & $3.96(1.14)$ & 34 & $4.21(1.12)$ & NS \\
\hline $\begin{array}{l}\text { I feel comfortable approaching my } \\
\text { faculty contact with questions or } \\
\text { concerns about my major }\end{array}$ & 62 & $3.68(1.40)$ & 25 & $3.64(1.35)$ & 34 & $3.71(1.47)$ & NS \\
\hline $\begin{array}{l}\text { I feel comfortable discussing } \\
\text { professional plans with my faculty } \\
\text { contact }\end{array}$ & 62 & $3.87(1.36)$ & 25 & $3.76(1.36)$ & 34 & $4.00(1.39)$ & NS \\
\hline $\begin{array}{l}\text { I feel comfortable discussing } \\
\text { personal/life questions with my } \\
\text { faculty contact }\end{array}$ & 62 & $2.66(1.41)$ & 25 & $2.64(1.35)$ & 34 & $2.74(1.52)$ & NS \\
\hline Overall Faculty Support $\dagger$ & -- & $3.65(0.47)$ & -- & $3.63(0.44)$ & -- & $3.73(0.48)$ & NS \\
\hline & & SME & & -Design & & & \\
\hline & $\mathbf{n}$ & M(SD) & $\mathbf{n}$ & M(SD) & $p$ & & \\
\hline $\begin{array}{l}\text { I feel comfortable asking my faculty } \\
\text { contact questions about what } \\
\text { courses to take }\end{array}$ & 39 & $3.49(1.52)$ & 16 & $4.06(1.18)$ & NS & & \\
\hline $\begin{array}{l}\text { I feel like my faculty contact } \\
\text { respects me }\end{array}$ & 39 & $4.15(1.09)$ & 17 & $3.59(1.06)$ & NS & & \\
\hline $\begin{array}{l}\text { I feel like my faculty contact wants } \\
\text { me to succeed }\end{array}$ & 39 & $4.21(1.08)$ & 17 & $3.94(1.03)$ & NS & & \\
\hline $\begin{array}{l}\text { I feel comfortable approaching my } \\
\text { faculty contact with questions or } \\
\text { concerns about my major }\end{array}$ & 39 & $3.67(1.44)$ & 17 & $3.82(1.19)$ & NS & & \\
\hline $\begin{array}{l}\text { I feel comfortable discussing } \\
\text { professional plans with my faculty } \\
\text { contact }\end{array}$ & 39 & $3.92(1.33)$ & 17 & $4.00(1.17)$ & NS & & \\
\hline $\begin{array}{l}\text { I feel comfortable discussing } \\
\text { personal/life questions with my } \\
\text { faculty contact }\end{array}$ & 39 & $2.64(1.42)$ & 17 & $2.76(1.35)$ & NS & & \\
\hline Overall Faculty Support $\uparrow$ & -- & $3.68(0.53)$ & -- & $3.69(0.45)$ & NS & & \\
\hline
\end{tabular}

\section{Notes:}

Faculty Support Scale Cronbach's Alpha: 0.87

Item Prompt: Think about the faculty member you feel closest to (referred to below as faculty contact). Please indicate the extent to which you agree or disagree with each statement.

Likert scale, 1-5: Strongly Disagree - Strongly Agree

$\dagger$ Weighted mean computed from the individual variables using respective $\mathrm{n}$ for each variable $* p<.05, * * p<.01, * * * p<.001$ 


\subsection{The intersection of Self-Beliefs \& Major and Support Perceptions}

In the prior two sections we looked at the self-beliefs related to engineering and perceptions/sense of support expressed by undergraduate in the ME department being studied. These are two of the circles in our Climate Venn diagram shown in Figure 1. Now we look at how these two intersect. This is a preliminary exploration of this "intersection" question, using simple correlations. This means that we cannot say anything about causation, only what things seem to be related. The correlation table is presented in Table 10.

Table 10: Correlations between Major and Support Perceptions Scales and Self-Belief Scales

\begin{tabular}{|c|c|c|c|c|c|}
\hline $\begin{array}{l}\text { Perceptions/Sense } \\
\text { Of: }\end{array}$ & $\begin{array}{c}\text { Skill } \\
\text { Beliefs } \\
\text { (Table 3) }\end{array}$ & $\begin{array}{l}\text { Innovation } \\
\text { Self- } \\
\text { Efficacy } 6 \\
\text { (Table 4A) }\end{array}$ & $\begin{array}{c}\text { Engineering } \\
\text { Task Self- } \\
\text { Efficacy } \\
\text { (Table 4B) }\end{array}$ & $\begin{array}{l}\text { Engineering } \\
\text { Identity } \\
\text { (Table 5) }\end{array}$ & $\begin{array}{c}\text { Major } \\
\text { Fit } \\
\text { (Table } \\
6)\end{array}$ \\
\hline $\begin{array}{l}\text { Major Perception } \\
\text { (Table 7) }\end{array}$ & 0.22 & 0.12 & 0.09 & $0.38^{* * *}$ & $0.44 * * *$ \\
\hline $\begin{array}{c}\text { Engineering } \\
\text { Community } \\
\text { (Table 8) }\end{array}$ & 0.19 & 0.19 & $0.32 * *$ & $0.32 * *$ & $0.55^{* * *}$ \\
\hline $\begin{array}{c}\text { Faculty Support } \\
\text { (Table 9) }\end{array}$ & $0.40^{* * *}$ & 0.21 & 0.21 & $0.41 * * *$ & $0.45^{* * *}$ \\
\hline
\end{tabular}

Given that the overall motivation for this study of climate is how to improve climate, we look at how resources/supports that the department provides correlate with various measures of selfbelief. With this approach we can see that Major Perception (which is rooted in how students sense the presence and inclusion of diversity being supported in the department) is strongly and positively correlated with Engineering Identity and Major Fit. Interestingly, there is weak correlation with ETSE. Engineering Community (examining how students perceive/receive support from their peers, both in their major and outside of their major) is strongly correlated with ETSE, Engineering Identity and Major Fit. Faculty Support (examining to what extent and in what ways students feel supported by the faculty member they feel closest to) is strongly and positively correlated with Skill Beliefs, Engineering Identity and Major Fit.

These correlations begin to suggest that these resources/supports may work in different and complementary ways in building a positive climate.

Interestingly, ISE seems only weakly supported by the resources studied in this work. We have other research that shows that ISE is strongly supported by extra- and co-curricular experiences (Gilmartin et. al, 2017).

\subsection{Discussion}

As a department assessment tool, we learned several important findings about our students' beliefs and perceptions of supports and procedures. First we highlight some areas where our department is doing well; the students are highly confident that they can complete their 
undergraduate degrees and communicate technical information. Despite some more nuanced beliefs around social groups and communities, our students feel that their major is a good fit and that they can succeed in their major. The students also indicated that they generally feel supported by at least one faculty member in the department.

When we look at areas where the department could explore improvement, this survey points to increasing confidence in finding employment upon graduation (perhaps focusing on BS-Design) and in improving access to training/advising in building a large network. We also note that the average score for perceptions of a strong out-of-classroom community was $2.84 / 5$, below the neutral point on the agree-disagree scale. We plan to explore options for fostering a more tightlyknit student community potentially using building study spaces, academic and social activities outside of the classroom, and a peer advising program.

In comparing women and men across the Mechanical Engineering department majors, we are troubled that on a number of the self-belief measures (e.g., experimenting to understand how things work and to generate new ideas, integrating subsystems, analyzing systems, and troubleshooting failures) women expressed less confidence in their engineering and innovation skills. Women also expressed lower sense of engineering identity, a finding that is consistent in several research studies on engineering identity (Rinehart \& Watson, 1998; Metz, Brainard, \& Gillmore, 1999). When we look more closely at our engineering identity items, women see themselves as an engineer, have interest in solving problems and care about doing well with the same level of agreement as men, however, they feel less welcomed in engineering and that they do not have a lot in common with their peers. This is a key area for departmental exploration as social belonging has been shown to be important factor (Walton 2015) in academic success.

When we break down our survey results by BSME and BS-Design majors, it is troubling that BS-Design majors feel significantly less welcomed in engineering. On a more positive note, BSDesign majors expressed the same levels of engineering task self-efficacy as the BSME majors and were in fact more confident in aspects of engineering that are more emphasized in their major (e.g., building prototypes, generating new ideas and asking questions). The restructuring of course requirements for the new BSME major, though, might cause some shifting of intermajor dynamics - not all BSME students will be required to take certain mechanical design courses with BS-Design students, which is perhaps the strongest point of tension currently. Another way to consider this tension of feeling welcomed in engineering is to develop a course that more successfully shows the complementary nature of mechanical engineering and design, rather than further separating students.

This work is limited by the small sample size. That said, the findings are consistent with other, more informal data collection the department has undertaken in order to understand the culture/climate of the department, as well as more informal student social discussions about department climate.

\section{Implications, Next Steps \& Future Work}

The information from this climate survey will allow the department to work on building community both inside and outside of the classroom. We hope to place particular emphasis on 
making all students feel welcome, feel a sense of belonging, and able to take on leadership roles. Based on the feedback regarding faculty support, we will also be piloting a new model of advising.

We plan to continue data analysis on other aspects of the Climate Model in Figure 1, and further examine how student perceptions and self-beliefs impact their behaviors (study habits, time spent on various "life-tasks," extracurricular activities, etc.). This further analysis will enable us to better understand the complex interplay between formal classroom experiences and day-to-day choices, and work towards creating an environment where students can best take advantage of the opportunities university life has to offer.

While the Cronbach alphas were high on the variables, we need to run factor analysis on the independent variables to increase their "strength". Increasing the strength of the variables will allow us to shorten the survey, hopefully encouraging more students to complete the survey. Then we will potentially complete some modeling (e.g., dependent variable of Major Fit as a function of the supports).

We will conduct more in-depth analysis of this rich dataset, including looking at how the intersections may vary for different groups within the department. Additionally, while the population for this initial analysis was split by gender and major, but not both gender and major simultaneously. After creating a cumulative dataset by distributing the survey in the future, we will be able to conduct further analysis while considering the impact gender has within a major. This analysis could provide a more nuanced understanding of the student experience.

Lastly, another potential next step would be the study of the mechanical engineering departmental culture. Since the climate survey results shed light on the culture of the department, studying the culture within the department would provide a more expanded perspective on how the department functions and what aspects of the department could be improved upon.

This climate survey has provided a strong starting point to a department evaluation. Some of these questions are also being adapted for use in the survey given annually to graduating seniors, and will help to provide long-term data about the department climate. 


\section{References}

Benjamin Schneider, Mark G. Ehrhart, William H. Macey. 2013. "Organization Climate and Culture." Annual Revivew of Psychology (64): 361-388.

Callister, Ronda Roberts. 2006. "The Impact of Gender and Department Climate on Job Satisfaction and Intentions to Quit for Faculty in Science and Engineering Fields." Journal of Technology Transfer (31): 367-375.

Godfrey, E., Parker, L.. 2010. "Mapping the Cultural Landscape in Engineering Education." Journal of Engineering Education.

Cech, E.A., Waidzunas, T.J. 2011. "Navigating the heteronormativity of engineering: the experiences of lesbian, gay, and bisexual students." Engineering Studies 3 (1): 1-24.

Godfrey, J.E. 2003. "The Culture of Engineering Education and its Interaction with Gender: A Case Study of a New Zealand University." Curtin University of Technology.

Rinehart, J., Watson, K. 1998. "A Campus Climate Survey at Texas A\&M University." WEPAN National Conference. 93-100.

Riffle, R., Schneider, T., Hillard, A., Polander, E., Jackson, S., Des Autels, P., Wheatley, M. 2013. "A Mixed Methods Study of Gender, STEM Department Climate, and Workplace Outcomes." Journal of Women and Minorities in Science and Engineering 3 (19): 227 243.

Gilmartin, S.K, Chen, H.L, Schar, M.F., Jin, Q., Toye, G., Harris, A., Cao, E., Costache, E., Reithmann, M., Sheppard, S.D. 2017. "Designing a Longitudinal Study of Engineering Students' Innovation and Engineering Interests and Plans: The Engineering Majors Survey Project." Designing Education Lab, Stanford University, Stanford.

Sandler, B. R. 1986. "The Campus Climate Revisited: Chilly for Women Faculty, Administrators, and Graduate Students." Association of American Colleges.

Sax, L. J., Lehman, K. J., \& Blaney, J. M. (2016). Building Recruiting and Inclusion for Diversity (BRAID): Emerging Research on Diversifying the CS Major. Computing Research News, 28 (3), 11-12.

Schar, M., Gilmartin, S., Sheppard, S., (2017) " The Making of an Innovative Engineer: Academic and Life Experiences that Shape Engineering Task and Innovation SelfEfficacy," ASEE Annual Conference Proceedings.

Schein, E.H. 2016. Organizational Culture and Leadership. Hoboken: John Wiley and Sons.

Metz, S.S., Brainard, S., Gillmore, G. 1999. "National WEPAN Pilot Climate Survey: Exploring the Environment for Undergraduate Engineering Students." Session 4: Women Students and Faculty in Technical Fields. Institute of Electrical and Electronics Engineers.

Walton 2015. Two Brief Interventions to Mitigate a "Chilly Climate" Transform Women's Experience, Relationships, and Achievement in Engineering 